\title{
Nutritional and lactational effects on follicular development in the pig
}

\author{
H. Quesnel
}

INRA, UMR1079 Systèmes d'Elevage, Nutrition Animale et Humaine, F-35590 Saint-Cilles, France, Agrocampus Ouest, UMR 1079 SENAH, F-35000 Rennes, France

In sows, follicular development is inhibited during lactation, and weaning the piglets allows recruitment and selection of follicles that will undergo preovulatory maturation and ovulate. Lactation inhibits $\mathrm{GnRH}$ secretion, and in turn $\mathrm{LH}$ secretion, through neuroendocrine stimuli induced by suckling. Pituitary response to $\mathrm{GnRH}$ and the sensitivity of the hypothalamo-pituitary unit to oestradiol positive feedback are also reduced. The impact of lactation on the reproductive axis is further complicated by the physiological and metabolic adaptations that are developed for milk production and that depend on nutrient intake, nutrient needs and body reserves. A strongly catabolic state during lactation amplifies the inhibition of LH secretion, thereby inducing a delay of oestrus and ovulation after weaning. Nevertheless, post-weaning ovulation is less delayed nowadays than in the 1970's or $80^{\prime} \mathrm{s}$. Nutritional deficiency has also deleterious effects on embryo survival, which are likely related to alterations in follicular growth and maturation. The physiological mechanisms by which information on the metabolic changes is transmitted to the hypothalamuspituitary-ovary axis are not fully understood in the sow. Glucose, insulin and leptin are the most likely signals informing the hypothalamus of the metabolic state, yet their roles have not been definitely established. At the ovarian level, folliculogenesis is likely to be altered by the reduction in insulin and IGF-I concentrations induced by nutritional deficiency. More knowledge is needed at the intrafollicular level to better understand nutritional effects on follicular development, and also on occyte quality and embryo development.

\section{Introduction}

In sows, as in numerous mammalian species, parturition is followed by a period of anovulation. Suckling by piglets is the main factor that inhibits the activity of the hypothalamo-pituitaryovarian axis and the nutritional deficiency related to milk production can amplify the inhibition of the reproductive axis. Lactational and nutritional effects on fertility in sows have been extensively reviewed (Britt et al. 1985, Aherne \& Kirkwood 1985, Foxcroft 1992, Einarsson \& Rojkittikhun 1993, Quesnel \& Prunier 1995). However, nutritional effects on reproductive performance after weaning appear to have changed over the past 20 years towards less delayed ovulation after weaning and deleterious effects are frequently reported on embryo survival (Table 1). Moreover, extensive research has been conducted to better understand the physiological and metabolic mechanisms underlying the nutritional effects on reproduction. The purpose of 
this review is first to update knowledge on the impacts of lactation and nutrition on follicular development, and second to examine potential mechanisms mediating these effects.

Table 1. Influence of feed or protein supply (High or Low) during lactation on the weaning-to-oestrus interval (WOI), ovulation rate (OR) and embryo survival (ES) in sows from first or second parity.

\begin{tabular}{|c|c|c|c|c|c|c|c|}
\hline \multirow[t]{2}{*}{ References } & \multirow[b]{2}{*}{ Parily } & \multicolumn{2}{|c|}{ WOI (days) } & \multicolumn{2}{|c|}{ OR } & \multicolumn{2}{|c|}{ ES $(\%)$} \\
\hline & & High & Low & High & Low & High & Low \\
\hline \multicolumn{8}{|l|}{ Feed supply } \\
\hline Mullan et al.1991 & 1 & 8.7 & $19.2^{*}$ & - & $\cdot$ & - & - \\
\hline Zak et al. 1997a & 1 & 3.7 & $5.4^{*}$ & 19.9 & $15.4^{*}$ & 87 & $64^{*}$ \\
\hline Zak et al. 1998 & 1 & 4.2 & $6.3^{*}$ & 14.4 & 15.6 & 83 & 72 \\
\hline Van den Brand et al. 2000 & 1 & 5.1 & 5.4 & 18.2 & $16.9^{\dagger}$ & & \\
\hline Vinsky et al. 2006 & 1 & 5.3 & 5.4 & 18.3 & 18.2 & 79 & $68^{*}$ \\
\hline Kirkwood et al. 1987 & 2 & 4.3 & $5.8^{*}$ & 18.2 & 18.7 & 83 & $68^{*}$ \\
\hline Kirkwood et al. 1990 & 2 & 6.0 & $8.9^{*}$ & 17.6 & 17.7 & 83 & $72^{*}$ \\
\hline Baidoo et al. 1992 & 2 & 5.9 & $7.3^{*}$ & 16.4 & 17.2 & 81 & $67^{*}$ \\
\hline \multicolumn{8}{|l|}{ Protein supply } \\
\hline King \& Martin 1989 & 1 & 7.5 & $16.0^{*}$ & & & & \\
\hline Jones \& Stahly 1999 & 1 & 7.7 & $11.7^{*}$ & & & & \\
\hline Mejia-Guadarrama et al. 2002 & 1 & 5.4 & 5.3 & 23.4 & $20.0^{*}$ & 72 & 73 \\
\hline
\end{tabular}

$* \mathrm{P}<0.05$; $^{\prime} \mathrm{P}<0.1$.

\section{Effect of nursing and milk production on follicular development}

Neuroendocrine and metabolic consequences of nursing and milk production

In sows, the effects of nursing and milk production cannot be dissociated since lactation is not maintained without suckling by the young. During lactation, stimulation of the teats by piglets and piglet proximity elicit neuroendocrine reflexes that induce the release of neurotransmitters and neuropeptides in the central nervous system of the sow. Neuropeptides include the endogenous opioid peptides (EOP) that have a morphine-like biological activity and include endorphins, enkephalins and dynorphins. These factors, in turn, stimulate the secretion of the pituitary hormones, prolactin, growth hormone $(\mathrm{GH})$, adrenocorticotropin (ACTH), thyroidstimulating hormone (TSH) and oxytocin (Fig. 1, reviewed by Kraeling \& Barb 1990, Estienne \& Barb 2005). Thereby, secretion of insulin-like growth factor I (IGF-I), cortisol and thyroid hormones is also stimulated.

These hormones are involved in milk production through different pathways including the regulation of udder development, nutrient uptake and body reserves mobilization (for review, see Père et al. 2008). Oxytocin plays an essential role in milk ejection during each nursing, but could also facilitate the mobilization of body reserves (Valros et al. 2004). Prolactin is essential for the initiation and the maintenance of milk production, and milk protein synthesis (Farmer et al. 2008). Elevated concentrations of GH are thought to favour the preferential drive of glucose and lipids to the mammary gland through the anti-lipogenic action of this hormone. Together with elevated concentrations of IGF-I, they could also minimize mobilization of endogenous proteins and thus spare lean tissue. Cortisol is known to enhance mobilization of energetic substrates from body reserves and thyroid hormones stimulate protein synthesis by the mammary gland, amongst many metabolic actions.

Because of the great use of glucose by the mammary gland, mean blood concentrations of glucose are lower during lactation than during pregnancy. In contrast, concentrations of non- 


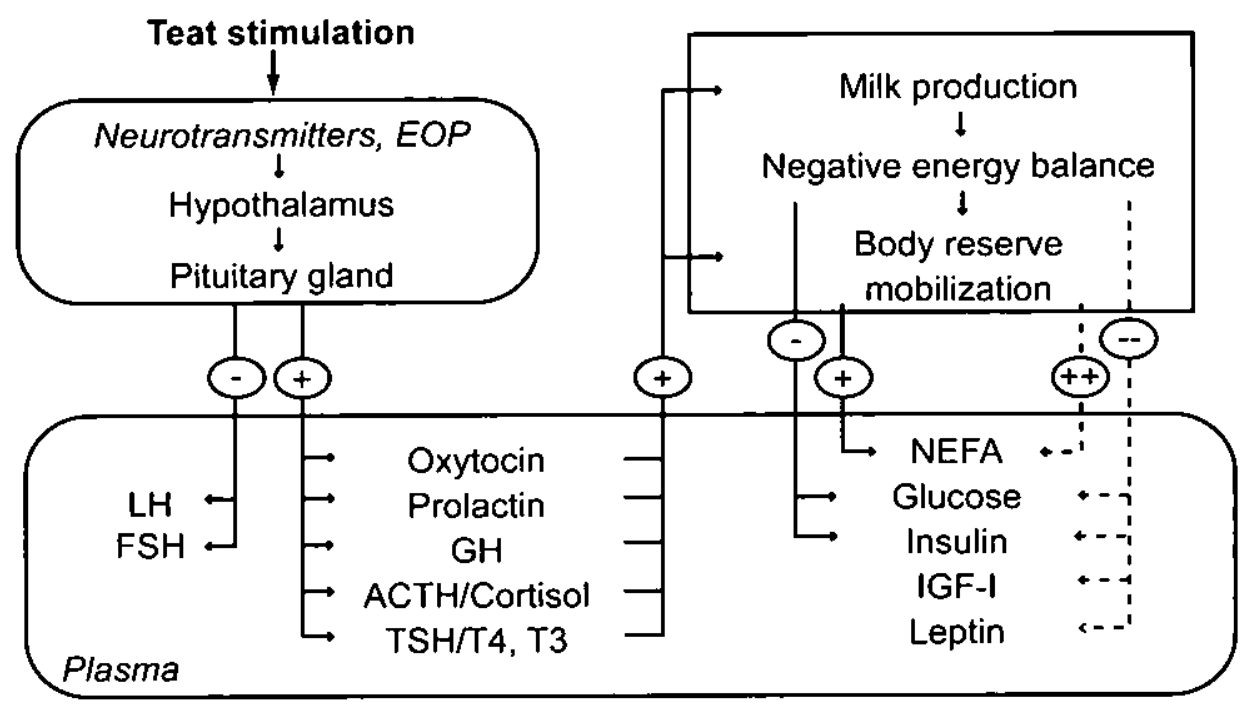

Fig. 1 Schematic representation of neuroendocrine and metabolic consequences of suckling and milk production.

Energy balance of sows during lactation may vary from moderately (plain line) to highly negative (interrupted lines). Plasma concentrations of metabolites and metabolic hormones are summarized from various studies (e.g. Rojkittikhun et al. 1992, Schams et al. 1994, Kraetzl et al. 1998, Quesnel et al. 1998a, Govoni et al. 2007).

EOP: endogenous opioid peptides, NEFA: non-esterified fatty acids, ACTH: adrenocorticotropin, TSH: thyroid-stimulating hormone, $\mathrm{LH}$ : luteinizing hormone, FSH: follicle-stimulating hormone.

esterified fatty acids (NEFA) are elevated during lactation, which indicates lipid mobilization from adipose tissue. Fat catabolism is induced by the elevated concentrations of $\mathrm{GH}$ and also by energy deficiency when sows are not allowed to consume feed ad libitum in early lactation. Elevated concentrations of NEFA are believed to induce the peripheral insulin resistance observed during lactation (Père \& Etienne 2007), which is a major physiological adaptation to enhance glucose availability for the mammary gland. Preprandial concentrations of glucose and insulin generally decrease as lactation progresses and milk production increases.

In situations of severe nutritional deficiency, further physiological and metabolic adaptations are developed to maintain a high level of milk production at the expense of maternai body reserves (Fig. 1). Such adaptations are observed in high-yielding multiparous sows and also in most primiparous sows because they have a lower feed intake than multiparous sows but a relatively high milk production. When sows are in a strongly catabolic state induced by feed or protein restriction, IGF-I concentrations are reduced presumably because of the uncoupling of the link between GH and IGF-I secretion (Quesnel et al.1998a, 2005a, Mejia-Guadarrama et al. 2002). A low level of IGF-I facilitates the mobilization of endogenous protein, which provides amino acids that may be used for gluconeogenesis and milk protein synthesis. Insulin secretion is reduced which allows further mobilization of lipids from adipose tissue. Feed restriction also affects post-prandial concentrations of leptin (Mao et al. 1999), but not pre-prandial concentrations (Prunier et al. 2001, Estienne et al. 2003). Pre-prandial concentrations appear to be highly influenced by sow adiposity (Estienne et al. 2000, 2003, de Rensis et al. 2005). 
Effects of suckling on the reproductive axis

During the last month of pregnancy, follicular development and LH secretion are inhibited by progesterone and oestrogens secreted by corpora lutea and the foeto-placental units respectively (reviewed by Quesnel \& Prunier 1995). At parturition, circulating concentrations of progesterone and oestrogens fall and LH secretion immediately increases. Two or three days after parturition, LH secretion is inhibited again in suckled sows (de Rensis et al. 1993a). This suckling-related suppression of $\mathrm{LH}$ episodic secretion appears to be due to the inhibition of the GnRH pulse generator (Kraeling \& Barb 1990). The inhibitory effect is mainly due to EOP during established lactation, whereas its development in early lactation is opioid-independent (de Rensis et al. 1993b, 1998).

In addition to the inhibition of $\mathrm{GnRH}$ secretion, the pituitary responsiveness to $\mathrm{GnRH}$ is also altered (Quesnel \& Prunier 1995). It is low after parturition and increases as lactation progresses. The reduced responsiveness of the pituitary gland can be due the direct action of EOP on the adenohypophysis (Estienne \& Barb 2005). It may also be related to $\mathrm{LH}$ stores in the pituitary gland, which are depleted just after farrowing and are progressively restored during lactation.

Mean concentrations of plasma $\mathrm{LH}$ and number of $\mathrm{LH}$ pulses are low during the first two weeks of lactation, and then progressively increase (e.g. Shaw \& Foxcroft 1985, Jones \& Stahly 1999). This partial resumption of LH secretion can be permitted by the increase in pituitary LH-response to $\mathrm{GnRH}$ and (or) by a decrease in suckling intensity in the course of lactation. Indeed, the total time spent nursing was shown to decrease from the $13^{\text {th }}$ day of lactation onwards (Valros et al. 2002). Variations in follicle-stimulating hormone (FSH) are less marked than variations in $\mathrm{LH}$, probably because $\mathrm{FSH}$ release is influenced by ovarian secretions during lactation (Quesnel \& Prunier 1995). Steroid secretion remains low during lactation and therefore does not influence $\mathrm{LH}$ secretion. In contrast, FSH secretion is inhibited by inhibin secreted by growing follicles (Wheaton et al. 1998).

In the ovaries, follicular growth up to $2 \mathrm{~mm}$ in diameter does not require gonadotrophic support; growth from 2 to $4 \mathrm{~mm}$ requires FSH support and is stimulated by $\mathrm{LH}$, while growth and maturation from $4 \mathrm{~mm}$ to the ovulatory size $(6-10 \mathrm{~mm})$ requires a high frequency of $\mathrm{LH}$ pulses. Consistently, large follicles $(\geq 5 \mathrm{~mm}$ ) can be observed on the ovaries after parturition, and then only small and medium-sized follicles (no larger than $3 \mathrm{~mm}$ ) are present during the second week of lactation. Afterwards, follicular growth resumes as a consequence of the progressive increase in the frequency of $\mathrm{LH}$ pulses. However, follicles generally do not develop beyond $5 \mathrm{~mm}$ in diameter during lactation. Beside this general pattern of follicular growth, great variability between sows has been reported in follicular populations before weaning. Using transrectal ultrasonography, Lucy et al. (2001) described sows with relatively inactive ovaries with no follicles larger than $2 \mathrm{~mm}$ in diameter and other sows with large follicles $(6$ $\mathrm{mm}$ ) present. These authors also suggested the existence of non-ovulatory follicular waves during the week before weaning, consisting of a cohort of follicles that grow to 4-6 mm and then regress. This needs to be further investigated.

During lactation, the positive feedback action of oestradiol on LH release is also impaired. After parturition, the hypothalamo-pituitary unit does not respond to oestrogen positive feedback and its responsiveness is partially recovered in the third and fourth weeks of lactation (for review, see Quesnel \& Prunier 1995). However, the amplitude of the LH surge after the injection of a massive dose of oestradiol benzoate remained lower than that observed in similarly treated cyclic or prepubertal gilts. The impaired responsiveness of the sows to oestradiol benzoate could be due to a low pool of LH stores or to the inhibitory effects of EOP on GnRH secretion and pituitary response to $\mathrm{GnRH}$. The dysfunction in the oestradiol-induced positive feedback 
could also be a long-term effect of pregnancy and parturition (Quesnel \& Prunier 1995). This hypothesis was based on studies in sows weaned just after parturition. Weaning piglets at birth, instead of 3 to 5 weeks after birth, induces a high incidence of anoestrus and cystic ovaries and delayed ovulation. Anoestrus and cystic ovaries probably result from a lack of an ovulatory LH surge due to reduced hypothalamic response to oestradiol positive feedback. Additionally, the duration of lactation influences the hypothalamic responsiveness to oestradiol in weaned sows; the amplitude of the LH surge induced by exogenous oestradiol is higher after 35 than after 21 of lactation (Edwards \& Foxcroft 1983).

\section{Effects of weaning on the reproductive axis}

Weaning the piglets removes the inhibition originating from the suckling stimuli, which induces an immediate increase in LH secretion and, although less clear, in FSH secretion. Some follicles are recruited and selected from a pool of medium-sized follicles $(2-3 \mathrm{~mm})$ to undergo preovulatory maturation and to ovulate, whereas the other medium-sized follicles become atretic. The preovulatory follicular growth and associated oestradiol production lead to oestrous behaviour and ovulation within 4 to 6 days after weaning, on average.

Variation in the weaning-to-oestrus interval (WOI) is related to the degree of inhibition of $\mathrm{LH}$ secretion during lactation (Shaw \& Foxcroft 1985). The degree of inhibition of $\mathrm{LH}$ secretion during lactation influences follicular development before weaning and the resumption of follicular growth after weaning (Quesnel et al. 1998b). Bracken et al. (2006) reported that the average diameter of follicles at weaning was one factor controlling the WOI duration. The degree of inhibition of $\mathrm{LH}$ secretion before weaning also influences $\mathrm{LH}$ secretion after weaning (Shaw \& Foxcroft 1985, van den Brand et al. 2000).

\section{Does the intensity of suckling modulate the activity of the reproductive axis?}

Assessing to what extent the intensity of suckling stimuli can modulate the inhibition of LH secretion is not easy. Most strategies that increase suckling intensity (e.g. increasing litter size, litter weight, age of nursed piglets or nursing frequency) also increase milk yield and can affect sow metabolic state. In multiparous sows, a reduction in $\mathrm{LH}$ secretion was reported in association with a longer average nursing duration and not in association with a more catabolic state (Hultén et al. 2002a, b). In an attempt to dissociate suckling and metabolic effects, we compared sows that nursed 13 or 14 piglets and were fed ad libitum to sows that nursed only 7 piglets and were subjected to feed restriction (Quesnel et al. 2007). The sows that nursed a large litter had smaller follicles at weaning than sows with a small litter. Yet, despite a similarly negative energy balance in sows from the two groups, plasma IGF-I concentrations were lower in sows that nursed a large litter. Therefore, we were not fully successful in maintaining an equivalent metabolic state across groups.

Although most sows remain anoestrus throughout lactation, ovulation can occur before weaning. Lactational ovulation is followed by a regular oestrous cycle of 21 days, thereby inducing a delayed oestrus after weaning. Because oestrous behaviour is not usually recorded during lactation, data are scarce on the incidence of lactational ovulation in commercial farms. In a field study based on 7 farms and 492 sows, $3 \%$ of sows on average were reported with lactational ovulation, as detected by high concentrations of progesterone at weaning (Auvigne et al. 2006). One may wonder whether strategies implemented at farm level to alleviate side 
effects of high prolificacy, such as partial weaning of the heaviest piglets, increase the incidence of lactational ovulation. Moreover, welfare concerns promote the development of housing systems that allow the animals to express their natural behaviour, such as group-housing. Hultén et al. (1995) reported that $28 \%$ of the sows housed in groups during weeks 4 and 5 of lactation ovulated before weaning, whereas none of the singly housed sows ovulated during the corresponding period.

\section{Nutritional effects on follicular development in the sow}

Impact of nutritional deficiency on performance of reproduction

A severe feed restriction associated with body weight loss during lactation delays oestrus after weaning in primiparous sows and to a lesser extent, in second-parity sows (Table 1). In the most recent experiments, the weaning-to-oestrus interval was little influenced by nutritional restriction during lactation (Table 1). This change is probably the consequence of indirect selection on WOI along with genetic selection on prolificacy. Together with the moderately extended WOI, deleterious effects of nutritional restriction are occasionally observed on ovulation rate and consistently on embryo survival (Table 1). Reduction in both ovulation rate and embryonic survival can partly explain the so-called "second litter syndrome" or "second parity dip", i.e. the smaller second litter as compared to the first one. Ultimately, a severe negative impact on embryo survival could explain the reduction in farrowing rate observed after the first weaning. In a field study including nearly 1700 sows, a longer weaning-to-service interval was reported when bodyweight loss during lactation increased above $5 \%$ for primiparous sows and above $10 \%$ for older sows (Thaker \& Bilkei 2005). Yet, all sows returned to oestrus within 7 days after weaning when bodyweight loss did not exceed $15 \%$. Subsequent farrowing rate and litter size were depressed when bodyweight loss exceeded $10 \%$.

\section{Nutritional effects at the hypothalamo-pituitary level}

Feed restriction associated with a strongly catabolic state inhibits the episodic secretion of LH during lactation (Mullan et al. 1991, Zak et al. 1997a, 1998, Quesnel et al. 1998b). Since the frequency of LH pulses is tightly controlled by the GnRH pulse generator, the nutritional anoestrus is likely due to the inhibition of $\mathrm{GnRH}$ secretion. It is worth noting that a severe restriction in crude protein or digestible energy also delays the post-weaning oestrus through impairment of $\mathrm{GnRH}$ and LH secretion during lactation (King \& Martin 1989, Koketsu et al. 1996, Jones \& Stahly 1999, Yang et al. 2000a). Such restrictions do not occur naturally in herds, but may help understand the mechanisms mediating nutritional effects.

Almond \& Dial (1990a, b) suggested that failure to return to oestrus after weaning might also be due, in part, to an increased sensitivity of the hypothalamo-pituitary unit to the negative feedback of oestrogens. In their experiments, however, anoestrus was thought to be due to the seasonal influence on reproduction. In ewes, seasonal anoestrus involves an increased sensitivity of the hypothalamus to oestradiol negative feedback and high feed intake can modify the sensitivity of the hypothalamus to oestradiol (Forcada \& Abecia 2006). To our knowledge, a nutritional influence on the sensitivity of the hypothalamo-pituitary unit to oestradiol has not been investigated in the sow. 
Metabolic mechanisms mediating nutritional effects at the hypothalamo-pituitary level

The relationships between nutrition and reproduction are most often viewed through energy balance. The influence of energy deficiency on $\mathrm{GnRH}$ secretion has been extensively reviewed (e.g. Barb et al. 2001a, Wade \& Jones 2004) and general pathways have been proposed. Feed intake modulates the availability of oxidizable metabolic fuels (glucose and fatty acids), which in turn modulate hormonal secretion (insulin, insulin-like growth factors, leptin, etc) by various organs and tissues. In the model proposed by Wade \& Jones (2004), available substrates and hormones can modulate the activity of the neurons of $\mathrm{GnRH}$ by two ways (Fig. 2). First, the availability in substrates could be detected by the area postrema, located in the hindbrain. This area has a permeable blood-brain barrier and can monitor substrate concentrations in the blood and cerebrospinal fluid. Second, metabolic hormones could modulate substrate availability and neuronal activity directly in the part of the forebrain which contains neurons of GnRH. The first pathway has been inferred from experiments in rodents and sheep where oxidization of substrates was inhibited by chemical inhibitors. In female rats and guinea pig, glucose deprivation induced by an inhibitor of glycolysis interrupts ovulatory cycles, but this effect disappears when the area postrema has previously been destroyed. However, lesions of the area postrema do not block the inhibitory effects of feed deprivation. Therefore, this pathway alone cannot explain the nutritional inhibition of $\mathrm{GnRH}$ secretion (Wade \& Jones 2004).

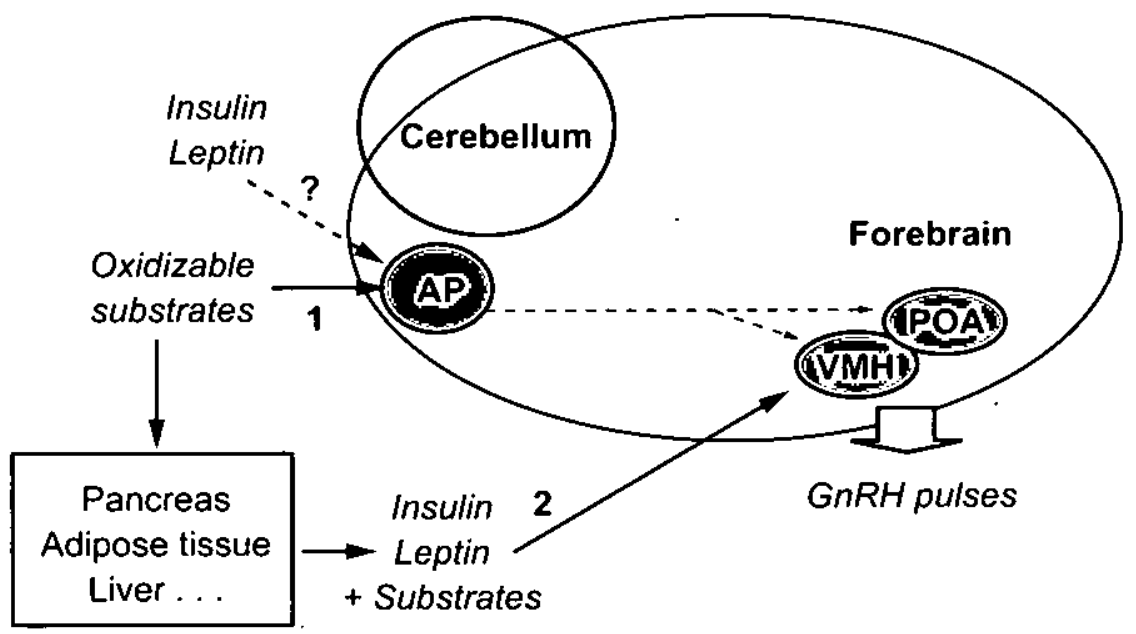

Fig. 2 Schematic representation of potential pathways by which nutrient availability could influence $\mathrm{GnRH}$ secretion, based on studies in rodents and small ruminants (adapted from Wade \& Jones 2004).

Pathway 1. The availability of oxidizable substrates (glucose and fatty acids) is detected by the area postrema (AP) and information is transmitted to the area which contains neurons of $\mathrm{CnRH}$ and neurons sensitive to sexual steroids (ventromedial hypothalamus - VMHand preoptic area - POA). Pathway 2. Metabolic substrates modulate hormonal secretion by various organs and tissues, which in turn can modulate the activity of the neurons of GnRH. 
In the sow, the metabolic mechanisms underlying the nutritional effect on the reproductive axis are not yet fully understood. In swine as in all monogastric animals, metabolic energy is mainly provided by glucose. In gilts, experimentally-induced glucose deprivation reduced LH pulse frequency (Barb et al. 2001b). Glucose administration to feed-restricted gilts, and the associated rise in circulating concentrations of insulin, induces a rapid increase in LH pulse frequency similar to that observed in response to refeeding (Booth 1990). Conversely, administration of insulin can stimulate LH secretion, as does increased energy supply (Cox et al. 1987). Based on experiments with diabetic pigs, it was suggested that insulin enhances the sensitivity of the hypothalamo-pituitary unit to ovarian positive feedback signal and pituitary responsiveness to GnRH (Cox et al. 1994, Angell et al. 1996). In lactating primiparous sows, increasing mean plasma concentrations of insulin and glucose by feeding a starch-rich diet compared to a fat-rich diet stimulates LH pulses in early lactation (van den Brand et al. 2000). Collectively, these findings support the hypothesis of a positive effect of glucose and insulin on $\mathrm{LH}$ secretion in the pig.

Leptin and IGF-I have been identified as putative signals linking metabolic state and neuroendocrine regulation of reproduction, thereby playing a role in puberty attainment in gilts (Barb et al. 2001b, 2008). In the post-partum sow, however, there is no evidence for a causal relationship between IGF-I and LH concentrations. Regarding leptin, Barb et al. (2008) described, in a very comprehensive review, how it is involved in the control of appetite, energy homeostasis and $\mathrm{LH}$ secretion. These authors suggested that leptin can link metabolic state and fertility in the gilt and also in the post-partum sow. However, the importance of the role of leptin in the prolonged lactational anoestrus has not been established. De Rensis et al. (2005) reported that fatter sows at farrowing had greater concentrations of leptin, lost more backfat during lactation and had extended WOI and reduced farrowing rate than thinner sows.

In contrast, it appears from literature on the influence of protein supply (Jones \& Stahly 1999, Yang et al. 2000a, Quesnel et al. 2005a) that restriction in protein alone during lactation impairs $\mathrm{LH}$ secretion without reducing fat tissue reserves and leptin concentrations. It induces an intense mobilization of endogenous protein and alters amino acids profiles. The reduced concentrations of insulin in protein-restricted sows could play a major role in mediating the inhibitory impact of protein restriction. Besides, as some amino acids are necessary for the synthesis of neurotransmitters involved in the secretion of $\mathrm{GnRH}$, we suggested that a reduction in their availability could participate in the inhibition of $\mathrm{GnRH}$ secretion during lactation (Quesnel et al. 2005a, b). This hypothesis needs to be further investigated.

\section{Physiological and metabolic mechanisms underlying nutritional effects at the ovarian level}

Compared with sows fed ad libitum, primiparous sows fed half the ad libitum feed supply had inhibited secretion of $\mathrm{LH}$, fewer follicles larger than $4 \mathrm{~mm}$ at weaning and two days later, and reduced follicular concentrations of IGF-I (Quesnel et al. 1998b). Clowes et al. (2003a, b) reported that protein restriction and the associated loss in maternal body protein impair folliculogenesis after weaning, as shown by reduced number and diameter of follicles and reduced follicular content of IGF-I and oestradiol at weaning. Additionally, follicular fluid recovered from sows subjected to feed or protein restriction showed a poor ability to support oocyte maturation in vitro (Zak et al. 1997b, Yang et al. 2000b, Clowes et al. 2003b). Nutritional deficiency during lactation can therefore alter both follicular growth and maturation after weaning.

Follicular development is controlled by interactions between gonadotrophins, metabolic hormones (such as insulin and IGF-I) and intra-ovarian growth factors (including IGFs; for review, see Webb et al. 2007). Notably, it is well established that insulin and IGF-I increase ovarian 
response to gonadotrophins and stimulate steroidogenesis (Adashi et al. 1992). Therefore, it is likely that reduced concentrations of insulin and SGF-I in feed-restricted sows impair ovarian responsiveness to the gonadotrophic stimulation at weaning and alter subsequent follicular development and ovulation rate. To our knowledge, however, there is no data on the nutritional effects on intra-follicular IGF binding proteins, which modulate IGF-I bioavailability. Whether elevated concentrations of $\mathrm{GH}$ during lactation may inhibit follicular development remains unknown, since both stimulatory and inhibitory actions of $\mathrm{GH}$ were reported on follicular steroidogenesis in vitro and in vivo.

The potential role of leptin at the ovarian level is not clear. Leptin has been shown to attenuate in vitro oestradiol secretion by follicular cells stimulated by insulin, IGF-I or gonadotrophins in several species, including the pig. Given that negative energy balance is associated with both low leptin and impaired folliculogenesis, it seems unlikely that direct effects of leptin at the ovarian level are involved in the impairment of folliculogenesis. Nevertheless, Gregoraszczuk et al. (2007) reported recently an in vitro synergistic action of leptin with IGF-I on oestradiol secretion by pig follicles. Another candidate, adiponectin, has been recently proposed as a mediator of the nutritional effects at the ovarian level. Adiponectin is an adipocyte-derived hormone that plays an important role in lipid metabolism and glucose homeostasis. It was shown to induce preovulatory changes in porcine granulosa cells in vitro (Ledoux et al. 2006) and to enhance the stimulatory action of IGF-I on steroidogenesis in the rat (Chabrolle et al. 2007). Low plasma concentrations of adiponectin have been associated with reproductive disorders related to obesity, including the polycystic ovarian syndrome (Campos et al. 2008). Whether adiponectin secretion is influenced by excessive fat loss associated with severe energy deficiency is not known.

Feed or protein restriction has also been shown to impair oocyte quality, i.e. its ability to be fertilized and develop into an embryo (Zak et al. 1997b, Yang et al. 2000b). Like follicular development, oocyte quality is influenced by a complex hormonal background, including gonadotrophins, IGF-I and steroids (Webb et al. 2007, Hunter \& Paradis, 2009). Extensive research has been conducted on nutritional effects on oocytes and embryos, mainly from cyclic gilts. Findings support the concept that alteration of these hormones may underlie the impact of nutritional inadequacy on oocyte quality. In turn, follicular and oocyte quality influences embryonic development and survival. To our knowledge, however, little is known on nutritional effects on intrafollicular characteristics (IGF system, glucose utilization, insulin and leptin receptors...). The metabolic cues supporting the impact of the metabolic state on oocyte maturation and embryo survival are beyond the scope of the present review.

interestingly, detrimental consequences on ovulation rate or embryo survival were mostly reported together with a relatively short WOI duration. Sow energy balance becomes positive as soon as piglets are weaned. However, metabolic state cannot be determined only as a function of energy balance, as previously shown (Quesnel et al. 2007, Zak et al. 2008). Consistently, IGF-I concentration requires several days after weaning before it is restored to normal (van den Brand et al. 2001, Mejia-Guadarrama et al. 2002). Presumably, these sows that ovulate soon after weaning have not fully recovered from their lactational catabolic state. Evidence for this hypothesis was provided by experiments where post-weaning insemination was delayed. Extending artificially the weaning-to-oestrus interval by treatment with altrenogest, an analogue of progesterone, or inseminating sows at the second oestrus after weaning ("skip-a-heat") resulted in increased ovulation rate and/or higher embryo survival (Martinat-Botté et al. 1994, Clowes et al. 1994, Wellen et al. 2007, Patterson et al. 2008). Moreover, delaying post-weaning ovulation increases the preovulatory size of the largest follicles by nearly $1 \mathrm{~mm}$ (Wellen et al. 2007, van Leeuwen et al. 2009). Whether a smaller ovulatory size reflects a reduced maturity and lower follicle and oocyte quality remains to be determined. 
Role of body reserves

There is evidence that maternal body reserves interact with feed or nutrient intake during lactation to influence post-weaning performance of reproduction.

We demonstrated that greater body weight at farrowing (and at weaning) played a protective role against the detrimental impact of a protein restriction in primiparous sows (Quesnel et al. $2005 \mathrm{~b}$ ). The protein restriction impaired the return to oestrus and reduced ovulation rate after weaning in sows weighing $180 \mathrm{~kg}$ at farrowing but not in sows weighing $240 \mathrm{~kg}$. Consistently, sows weighing $165 \mathrm{~kg}$ at farrowing had less developed ovaries at weaning than sows weighing $190 \mathrm{~kg}$, despite a similar protein deficiency during lactation (Clowes et al. 2003a). Large body reserves could partly prevent negative nutritional effects by providing energetic substrates and thereby attenuating metabolic and physiological perturbations.

\section{Conclusions}

Lactation inhibits $\mathrm{LH}$ secretion by inhibiting $\mathrm{GnRH}$ secretion and reducing pituitary response to GnRH. As lactation progresses, LH secretion increases, which allows resumption of folliculogenesis. The nutritional deficiency associated with mobilization of body reserves constitutes an additional inhibitory factor, which affects $\mathrm{LH}$ secretion and follicular maturation during lactation and after weaning. The lactational and nutritional effects at the different levels of the reproductive axis are likely to influence the ovarian response to lactation management strategies (e.g. short lactation duration, split-weaning, interrupted suckling), as reviewed by Soede et al. (2009). The metabolic mechanisms that affect folliculogenesis are not fully understood

- (Fig. 3). Glucose, insulin and leptin are the most likely signals at the hypothalamic level, yet their roles have not been definitely established. At the ovarian level, folliculogenesis is likely to be altered by the reduction in insulin and IGF-I concentrations induced by the nutritional deficiency. However, more knowledge on nutritional effects on intrafollicular characteristics, such as IGF, glucose/insulin and leptin systems, could provide a better understanding on nutritional effects on follicular development, occyte quality and embryo development.

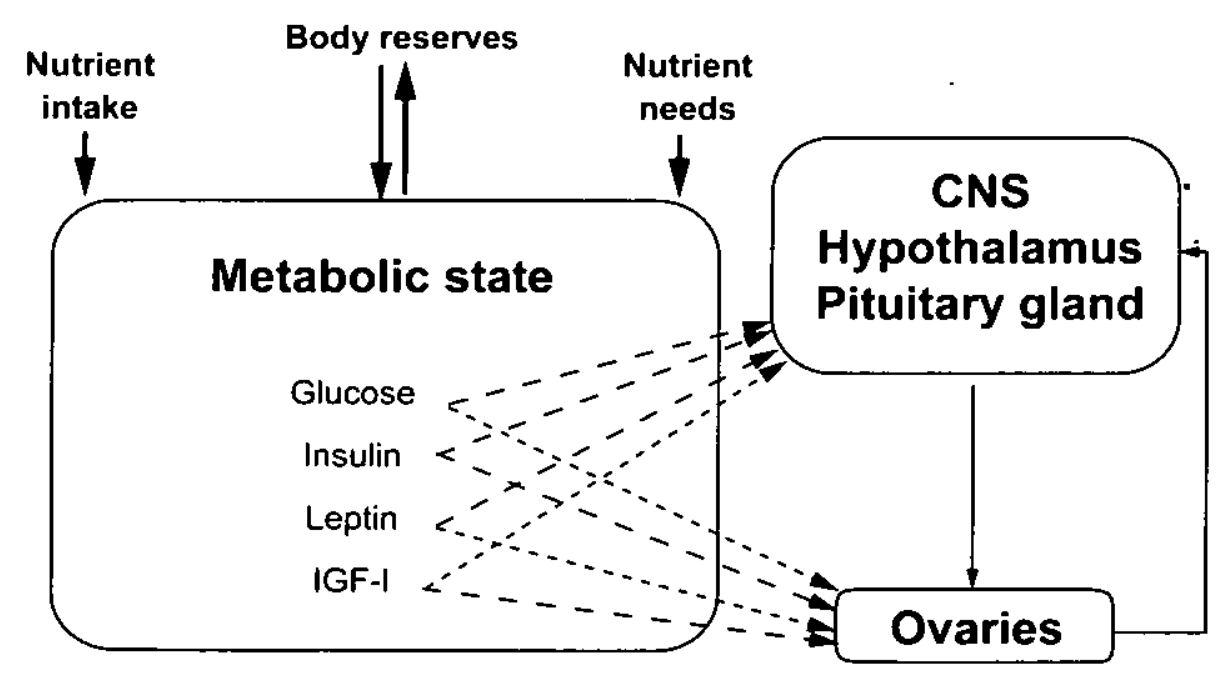

Fig. 3 Putative sites of action for metabolic substrates and metabolic hormones in the reproductive axis in the sow submitted to feed restriction.

Interrupted line: the potential stimulatory effect is reduced in situation of feed restriction. Dotted line: poor evidence of the effect in swine. 


\section{References}

Adashi EY, Resnick CE, Hurwitz A, Ricciarellie E, Hernandez ER, Roberts CT, LeRoith D \& Rosenfeld R 1992 The intra-ovarian IGF system. Growth Regulation 2 10-15.

Aherne FX \& Kirkwood RN 1985 Nutrition and sow prolificacy. Journal of Reproduction and Fertility Supplement 33 169-183.

Almond GW \& Dial GD 1990a The influence of ovariectomy on luteinizing hormone concentrations in anestrous and cyclic sows. Journal of Animal Science $68700-708$.

Almond GW \& Dial GD 1990b Estradiol feedback inhibition of luteinizing hormone concentrations in the anestrous sow. Journal of Animal Science $\mathbf{6 8}$ 1077-1086.

Angell CA, Tubbs RC, Moore AB, Barb CR \& Cox NM 1996 Depressed luteinizing hormone response to estradiol in vivo and gonadotropin-releasing hormone in vitro in experimentally diabetic swine. Domestic Animal Endocrinology 13 453-463.

Auvigne V, Avon J, Laval A \& Sallé E 2006 Lactational ovulations are a causative factor in long weaningto-oestrus intervals. In Proceedings of the $19^{\text {th }}$ IPVS Congress, Copenhagen, Denmark (Abstract).

Baidoo SK, Lythgoe ES, Kirkwood RN, Aherne FX \& Foxcroft GR 1992 Effect of lactation feed intake on endocrine status and metabolite levels in sows. Canadian lournal of Animal Science 72 799-807.

Barb CR, Kraeling RR \& Rampacek GB 2001a Nutritional regulators of the hypothalamic-pituitary axis in pigs. Reproduction Supplement 58 1-15.

Barb CR, Barrett JB, Kraeling RR \& Rampacek GB 2001b Serum leptin concentrations, luteinizing hormone and growth hormone secretion during feed and metabolic fuel restriction in the prepuberal gilt. Domestic Animal Endocrinology 20 47-63.

Barb CR, Hausman GJ \& Lents CA 2008 Energy metabolism and leptin: effects on neuroendocrine regulation of reproduction in the gilt and sow. Reproduction in Domestic Animals Supplement 2 43 324-330.

Booth PJ 1990 Metabolic influences on hypothalamicpituitary-ovarian function in the pig. Journal of Reproduction and Fertility Supplement 40 89-100.

Bracken CJ, Radcliff RP, McCormack BL, Keisler DH \& Lucy MC 2006 Decreased follicular size during late lactation caused by treatment with charcoal-treated follicular fluid delays onset of estrus and ovulation after weaning in sows. fournal of Animal Science $\mathbf{8 4}$ 2110-2117.

Britt JH, Armstrong JD, Cox NM \& Esbenshade KL 1985 Control of follicular development during and after lactation in sows. Journal of Reproduction and Fertility Supplement 33 37-54.

Campos DB, Palin MF, Bordignon V \& Murphy BD 2008 The 'beneficial' adipokines in reproduction and fertility. International Journal of Obesity 32 223-231.

Chabrolle C, Tosca L \& Dupont J 2007 Regulation of adiponectin and its receptors in rat ovary by human chorionic gonadotrophin treatment and potential involvement of adiponectin in granulosa cell steroidogenesis. Reproduction 133 719-731.

Clowes EJ, Aherne FX \& Foxcroft GR 1994 Effect of delayed breeding on the endocrinology and fecundity of sows. Journal of Animal Science 72 283-291.

Clowes EJ, Aherne FX, Schaefer AL, Foxcroft GR \& Baracos VE 2003a Parturition body size and body protein loss during lactation influence performance during lactation and ovarian function at weaning in first-parity sows. Journal of Animal Science 81 1517-1528.

Clowes EJ, Aherne FX, Foxcroft GR \& Baracos VE 2003b Selective protein loss in lactating sows is associated with reduced litter growth and ovarian function. Journal of Animal Science 81 753-764.

Cox NM, Stuart MJ, Althen TG, Bennett WA \& Miller HW 1987 Enhancement of ovulation rate in gilts by increasing dietary energy and administering insulin during follicular growth. Journal of Animal Science 64 507-516.

Cox NM, Meurer KA, Carlton CA, Tubbs RC \& Mannis DP 1994 Effect of diabetes mellitus during the luteal phase of the oestrous cycle on preovulatory follicular function, ovulation and gonadotrophins in gilts. Journal of Reproduction and Fertility 101 77-86.

De Rensis F, Hunter MG \& Foxcroft GR 1993a Sucklinginduced inhibition of luteinizing hormone secretion and follicular development in the early postpartum sow. Biology of Reproduction 48 964-969.

De Rensis F, Cosgrove JR \& Foxcroft GR 1993b Luteinizing hormone and prolactin responses to naloxone vary with stage of lactation in the sow. Biology of Reproduction 48 970-976.

De Rensis F, Cosgrove JR \& Foxcroft GR 1998 Ontogeny of the opioidergic regulation of $\mathrm{LH}$ and prolactin secretion in lactating sow I: failure of naloxone to antagonize suckling-induced changes in $\mathrm{L.H}$ and prolactin secretion in early lactation, irrespective of pattern of administration. Journal of Reproduction and Fertility 112 79-85.

De Rensis F, Gherpelli M, Superchi P \& Kirkwood RN 2005 Relationships between backfat depth and plasma leptin during lactation and sow reproductive performance after weaning. Animal Reproduction Science 90 95-100.

Edwards S \& Foxcroft GR 1983 Response of sows to oestradiol benzoate treatment after weaning at two stages of lactation. Journal of Reproduction and Fertility 67 173-180.

Einarsson S \& Rojkittikhun T 1993 Effects of nutrition on pregnant and lactating sows. Journal of Reproduction and Fertility Supplement 48 229-239.

Estienne M) \& Barb CR 2005 The control of adenohypophysial hormone secretion by amino acids and peptides in swine Domestic Animal Endocrinology 29 34-42.

Estienne MJ, Harper AF, Barb CR \& Azain MJ 2000 Concentrations of leptin in serum and milk collected 
from lactating sows differing in body condition. Domestic Animal Endocrinology 19 275-280.

Estienne MJ, Harper AF, Kozink DM \& Knight JW 2003 Serum and milk concentrations of leptin in gilts fed a high- or low-energy diet during gestation. Animal Reproduction Science 75 95-105.

Farmer C, Guan X \& Trottier NL 2008 Mammary arteriovenous differences of glucose, insulin, prolactin and IGF-I in lactating sows under different protein intake levels. Domestic Animal Endocrinology 34 54-62.

Forcada F \& Abecia JA 2006 The effect of nutrition on the seasonality of reproduction in ewes. Reproduction Nutrition Development 46 355-365.

Foxcroft GR 1992 Nutritional and lactational regulation of fertility in sows. Journal of Reproduction and Fertility Supplement 45 113-125.

Govoni N, Parmeggiani A, Galeati G, Penazzi P, De lasio R, Pagotto U, Pasquali R, Tamanini C \& Seren E 2007 Acyl ghrelin and metabolic hormones in pregnant and lactating sows. Reproduction in Domestic Animals 42 39-43.

Gregoraszczuk El., Ptak A, Wojciechowicz T \& Nowak K 2007 Action of IGF-I on expression of the long form of the leptin receptor (ObRb) in the prepubertal period and throughout the estrous cycle in the mature pig ovary. Journal of Reproduction and Development 53 289-295

Hultén F, Dalin AM, Lundeheim N \& Einarsson S 1995 Ovulation frequency among sows group-housed during late lactation. Animal Reproduction Science 39 223-233.

Hultén F, Valros A, Rundgren M \& Einarsson S 2002a Reproductive endocrinology and postweaning performance in the multiparous sow Part 1. Influence of metabolic status during lactation. Theriogenology 58 1503-1517.

Hultén F, Valros A, Rundgren M \& Einarsson S 2002b Reproductive endocrinology and postweaning performance in the multiparous sow Part 2. Influence of nursing behavior. Theriogenology 58 1519-1530.

Hunter MC \& Paradis F 2009 Intra-Follicular Regulatory Mechanisms in the Porcine Ovary. In Control of Pig Reproduction VIII, pp 149-164. Eds $H$ RodriguezMartinez, IL Vallet and AJ Ziecik, Nottingham University Press, Nottingham.

Jones DB \& Stahly TS 1999 Impact of amino acid nutrition during lactation on luteinizing hormone secretion and return to estrus in primiparous sows. Journal of Animal Science 77 1523-1531.

King RH \& Martin GB 1989 Relationships between protein intake during lactation, $\mathrm{L} . \mathrm{H}$ levels and oestrus activity in first-litter sows. Animal Reproduction Science 19 283-292.

Kirkwood RN, Baidoo SK, Aherne FX \& Sather AP 1987 The influence of feeding level during lactation on the occurrence and endocrinology of the postweaning estrus in sows. Canadian Journal of Animal Science $67405-415$

Kirkwood RN, Baidoo SK \& Aherne FX 1990 The influence of feeding level during lactation and gestation on the endocrine status and reproductive performance of second parity sows. Canadian Journal of Animal Science 70 1119-1126.

Koketsu Y, Dial GD, Pettigrew JE, Marsh WE \& King VL 1996 Influence of imposed feed intake patterns during lactation on reproductive performance and on circulating levels of glucose, insulin, and luteinizing hormone in primiparous sows. Journal of Animal Science 74 1036-1046.

Kraeling RR \& Barb CR 1990 Hypothalamic control of gonadotrophin and prolactin secretion in pigs. Journal of Reproduction and Fertility Supplement 40 3-17.

Kraetzl WD, Zimmer C, Schneider D \& Schams D 1998 Secretion pattern of growth hormone, prolactin, insulin and insulin-like growth factor- 1 in the periparturient sow depending on the metabolic state during lactation. Animal Science 67 339-347.

Ledoux S, Campos DB, Lopes FL, Dobias-Goff $M$, Palin MF \& Murphy BD 2006 Adiponectin induces periovulatory changes in ovarian follicular cells. Endocrinology 147 5178-5186.

Lucy MC, Liu J, Boyd CK \& Bracken CJ 2001 Ovarian follicular growth in sows. Reproduction Supplement 58 31-45.

Mao J, Zak LJ, Cosgrove JR, Shostak S \& Foxcroft GR 1999 Reproductive, metabolic, and endocrine responses to feed restriction and $\mathrm{GnRH}$. Journal of Animal Science 77 724-735.

Martinat-Botté F, Bariteau F, Forgerit $Y$, Macar $C$, Poirier P \& Terqui M 1994 Control of reproduction with a progestagen -altrenogest (Regumate) in gilts and at weaning in primiparous sows: effect on fertility and litter size. Reproduction in Domestic Animals 29 362-365.

Mejia-Guadarrama CA, Pasquier A, Dourmad JY, Prunier A \& Quesnel H 2002 Protein(lysine) restriction in primiparous lactating sows: Effects on metabolic state, somatotropic axis and reproductive performance after weaning. Journal of Animal Science $803286-3300$.

Mullan BP, Close WH \& Foxcroft GR 1991 Metabolic state of the lactating sows influences plasma $\mathrm{L} . \mathrm{H}$ and FSH before and after weaning. In Manipulating Pig Production III, p. 32. Ed ES Batterham, Victoria: Australasian Pig Science Association.

Patterson J, Wellen A, Hahn M, Pasternak A, Lowe J, DeHaas S, Kraus D, Williams N \& Foxcroft G 2008. Responses to delayed estrus after weaning in sows using oral progestagen treatment. Journal of Animal Science 86 196-2004.

Père MC \& Etienne $M 2007$ Insulin sensitivity during pregnancy, lactation, and postweaning in primiparous gilts. Journal of Animal Science 85 101-110.

Père MC, Quesnel H \& Etienne M 2008 The metabolic status of the lactating sow: Consequences on milk production and post-weaning reproductive performance. In Proceedings of the $/ I$ Congress of CLANA (Colegio Latino Americano de Nutrición Animal), pp 34-47, Cancun, Mexico.

Prunier A, Mejia-Guadarrama CA., Mourot I \& Quesnel H 2001 Influence of feed intake during pregnancy and lactation on fat body reserve mobilization, plasma 
leptin and reproductive function of primiparous lactating sows. Reproduction Nutrition Development 41 333-347.

Quesnel H \& Prunier A 1995. Endocrine bases of lactational anoestrus in the sow. Reproduction Nutrition Development 35 395-414.

Quesnel H, Pasquier A, Mounier AM, Louveau 1 \& Prunier A 1998a Influence of feed restriction in primiparous lactating sows on body condition and metabolic parameters. Reproduction Nutrition Development 38 261-274.

Quesnel H, Pasquier A, Mounier AM \& Prunier A $1998 \mathrm{~b}$ Influence of feed restriction during lactation on gonadotropic hormones and ovarian development in primiparous sows. Journal of Animal Science 76 856-863.

Quesnel H, Mejia-Guadarrama C, Dourmad JV, Farmer C \& Prunier A 2005 a Dietary protein restriction during lactation in primiparous sows with different live weight at farrowing: I. Consequences on sow metabolic state and litter growth. Reproduction Nutrition Development 45 39-56.

Quesnel H, Mejia-Guadarrama C, Pasquier A, Dourmad IY \& Prunier A 2005b Dietary protein restriction during lactation in primiparous sows with different live weights at farrowing: II. Consequences on reproductive performance and interactions with metabolic state. Reproduction Nutrition Development 45 57-68.

Quesnel H, Etienne M \& Père MC 2007 Influence of litter size on metabolic status and reproductive axis in primiparous sows. Journal of Animal Science $\mathbf{8 5}$ 118-128.

Rojkittikhun T, Einarsson S, Edqvist LE, Uvnäs-Moberg $K$ \& Lundeheim N 1992 Relationship between lactationassociated body weight loss, levels of metabolic and reproductive hormones and weaning-to-oestrous interval in primiparous sows. Journal of Veterinary Medicine $39426-432$

Schams D, Kraetzl WD, Brem G \& Graf F 1994 Secretory pattern of metabolic hormones in the lactating sow. Experimental and Clinical Endocrinology $102439-447$.

Shaw HJ \& Foxcroft GR 1985 Relationships between LH, FSH and prolactin secretion and reproductive activity in the weaned sow. Journal of Reproduction and Fertility 75 17-28.

Soede NM, Hazeleger W, Langendijk P \& Kemp B 2009 Variable ovarian responses to lactation management strategies. In Control of Pig Reproduction VIII, pp 177-186. Eds H Rodriguez-Martinez, JL. Vallet and AJ Ziecik, Nottingham University Press, Nottingham.

Thaker MYC \& Bilkei G 2005 Lactation weight loss influences subsequent reproductive performance of sows. Animal Reproduction Science 88 309-318.

Valros A, Rundgren M, Špinka M, Saloniemi H, Rydhmer L \& Algers B 2002 Nursing behaviour of sows during 5 weeks lactation and effects on piglet growth. Applied Animal Behaviour Science 76 93-104.

Valros A, Rundgren M, Špinka M, Saloniemi H, Hultén F, Uvnäs-Moberg K, Tománek $M$, Krejcí \& Algers B 2004 Oxytocin, prolactin and somatostatin in lactating sows: associations with mobilisation of body resources and maternal behaviour. Livestock Production Science 85 3-13.

van den Brand $H$, Dieleman SI, Soede NM \& Kemp B 2000 Dietary energy source at two feeding levels during lactation of primiparous sows. 1. Effects on glucose, insulin, and $\mathrm{LH}$ and on follicle development, weaning-to-estrus-interval and ovulation rate. Journal of Animal Science 78 396-404.

van den Brand H, Prunier A, Soede NM \& Kemp B 2001 In primiparous sows, plasma insulin-like growth factor-l can be affected by lactational feed intake and dietary energy source and is associated with luteinising hormone. Reproduction Nutrition Development 41 27-39.

van Leeuwen JJ,, Williams S, Kemp B \& Soede NM 2009. Post-weaning altrenogest treatment in primiparous sows; the effect of duration and dosage on follicular development and consequences for early pregnancy. In Control of Pig Reproduction VIII, pp 197-198. Eds H Rodriguez-Martinez, JL Vallet and Al Ziecik, Nottingham University Press, Nottingham.

Vinsky MD, Novak S, Dixon WT, Dyck MK \& Foxcroft GR 2006 Nutritional restriction in lactating primiparous sows selectively affects female embryo survival and overall litter development. Reproduction, Fertifity \& Development 18 347-355.

Wade GN \& Jones JE 2004 Neuroendocrinology of nutritional infertility. American lournal of Physiology 287 R1277-R1296.

Webb R, Garnsworthy PC, Campbell BK \& Hunter MG 2007 Intra-ovarian regulation of follicular development and oocyte competence in farm animals. Theriogenology 68 S S22-S29.

Wellen A, Patterson JL, Zimmerman P, Dyck M \& Foxcroft GR 2007 Effect of "skip-a-heat" breeding on reproductive performance of weaned first parity sows. Journal of Animal Science 86 (E Suppl. 3) 102 (Abstract).

Wheaton JE, Meyer RL, Jones RH \& Kramer AJ 1998 Effects of passive immunization using antibody against an $\alpha$-inhibin peptide on follicle-stimulating hormone concentration and litter size in sows. Theriogenology 49 813-822.

Yang $H$, Pettigrew JE, Johnston LJ, Shurson CC, Wheaton JE, White ME, Koketsu Y, Sower AF \& Rathmacher JA 2000a Effects of dietary lysine intake during lactation on blood metabolites, hormones, and reproductive performance in primiparous sows. Journal of Animal Science 78 1001-1009.

Yang H, Foxcroft GR, Pettigrew JE, Johnston LJ, Shurson GC, Costa AN \& Zak LJ 2000b Impact of dietary lysine intake during lactation on follicular development and oocyte maturation after weaning in primiparous sows. Journal of Animal Science 78 993-1000.

Zak LJ, Cosgrove JR, Aherne FX \& Foxcroft GR 1997a Pattern of feed intake and associated metabolic and endocrine changes differentially affect postweaning fertility in primiparous lactating sows. Journal of Animal Science 75, 208-216.

Zak LJ, Xu X, Hardin RT \& Foxcroft GR 1997b Impact of different patterns of feed intake during lactation 
in the primiparous sow on follicular development and oocyte maturation lournal of Reproduction and Fertility 110 99-106.

Zak LJ, Williams IH, Foxcroft GR, Pluske JR, Cegielski AC, Clowes E) \& Aherne FX 1998 Feeding lactating primiparous sows to establish three divergent metabolic states: I. Associated endocrine changes and postweaning reproductive performance. Journal of Animal Science 76 1145-1153.

Zak L, Foxcroft GR, Aherne FX \& Kirkwood RN 2008 Role of luteinizing hormone in primiparous sow responses to split weaning. Reproduction in Domestic Animals 43 445-450. 